\title{
PENINGKATAN MOTIVASI KERJA APARATUR DALAM PENYELENGGARAAN PEMERINTAHAN DI KANTOR KECAMATAN BARANTI KABUPATEN SIDENRENG RAPPANG
}

\author{
Nama:maria afrila odut \\ Npm:43181030 \\ Email:matiaafrilaodut@gmail.com
}

\begin{abstract}
Abstrak
Tujuan penelitian yaitu untuk mengetahui tentang Peningkatan Motivasi Kerja Aparatur dalam Penyelenggaraan Pemerintahan di Kantor Kecamatan Baranti Kabupaten Sidenreng Rappang dan untuk mengetahui Faktor-faktor yang memengaruhi Peningkatan Motivasi Kerja Aparatur dalam Penyelenggaraan Pemerintahan di Kantor Kecamatan Baranti Kabupaten Sidenreng Rappang.Populasi penelitian ini sebanyak 44 orang, sedangkan sampel yaitu berjumlah 44 orang. Teknik pengumpulan data yang dilakukan dalam penelitian ini adalah dengan menggunakan teknik (1)Observasi, (2) Wawancara, (3) Kuisioner, dan (4) Studi Pustaka. Data yang terkumpul kemudian dianalisis dengan menggunakan tabel frekuensi dan persentase. Hasil penelitian ini menunjukkan bahwa indikator Peningkatan Motivasi Kerja Aparatur dalam Penyelenggaraan Pemerintahan diKantor Kecamatan Baranti Kabupaten Sidenreng Rappang dengan capaian 67,57 \% kategori baik,Faktor-faktor yang memengaruhi Peningkatan Motivasi Kerja Aparatur dalam Penyelenggaraan Pemerintahan di Kantor Kecamatan Baranti Kabupaten Sidenreng Rappang yaitu faktor motivasi langsung terdiri dari faktor pujian $66 \%$, penghargaan $68 \%$, tunjangan hari raya $67 \%$, bonus $67 \%$ dengan capaian $67 \%$ kategori baik, faktor motivasi tak langsung terdiri dari mesin atau computer yang baik $69 \%$, ruangan kerja yang terang $66 \%$, suasana kerja $69 \%$, penempatan yang tepat $70 \%$, dengan capaian $67,75 \%$ dikategorikan baik.
\end{abstract}

Kata Kunci : Motivasi dan Penyelenggaraan Pemerintah

\author{
Abstract \\ The purpose of the study was to find out about Increasing Apparatus Work Motivation in \\ Government \\ Administration at the Baranti District Office, Sidenreng Rappang Regency and to find out the \\ factors \\ that influenced the Increasing Apparatus Work Motivation in Government Administration at the \\ Baranti District Office, Sidenreng Rappang Regency. The population of this study was 44 \\ people, \\ while the sample was 44 people. The data collection techniques used in this study were (1) \\ observation, (2) interviews, (3) questionnaires, and (4) literature studies. The collected data was \\ then analyzed using frequency and percentage tables. The results of this study indicate that the
}


indicators of Increasing Apparatus Work Motivation in Government Administration at the Baranti District Office, Sidenreng Rappang Regency with an achievement of $67.57 \%$ in the good category.

direct motivation consists of $66 \%$ praise factor, $68 \%$ award, $67 \%$ holiday allowance, $67 \%$ bonus with

$67 \%$ achievement in good category, indirect motivation factor consists of a good machine or computer $69 \%$, 66\% bright workspace, $69 \%$ working atmosphere, $70 \%$ right placement, with 67.75

$\%$ achievement categorized as good.

Keywords: Government Motivation and Implementation

\section{A. PENDAHULUAN}

Kecamatan dilihat dari system pemerintahan Indonesia, merupakan ujung tombak dari pemerintahan daerah yang langsung berhadapan dengan masyarakat luas. Citra birokrasi pemerintahan secara keseluruhan akan banyak ditentukan oleh kinerja organisasi tersebut. Masyarakat perkotaan yang peradabannya sudah cukup maju, mempunyai kompleksitas permasalahan lebih tinggi dibandingkan pada masyarakat tradisional sehingga diperlukan aparatur pelayanan yang profesional.(Mustanir et al., 2018) Ketidak tergantungannya kepada alam menyebabkan masyarakat kota sangat menghargai waktu.Persaingan yang ketat dan tajam menuntut adanya kecepatan, ketepatan, serta kecermatan pengambilan keputusan.Masyarakat perkotaan pada umumnya berorientasi ke masa depan. Penjelasan ini sejalan seperti yang dikemukakan oleh Ndraha (2001:88) bahwa dalam masyarakat yang tak berdaya bersifat menerima atau dibuat seperti itu, tuntutan tidak setajam dan tekanan terhadap struktur supra pada sistem politik tidak seberat jika masyarakat peka,sensitive, aktif, responsif dan vokal.Penyelenggaraan pemerintahan kecamatan memerlukan adanya seorang pemimpin yang selalu mampu untuk menggerakkan bawahannya agar dapat melaksanakan tugas dan tanggung jawabnya untuk berpartisipasi dalam kegiatan pemerintahan, pembangunan dan kemasyarakatan secara berdayaguna dan berhasil guna.(Mustanir et al., 2020) Keberhasilan pembangunan akan terlihat dari tingginya produktivitas, penduduk makmur dan sejahtera secara merata, Kondisi seperti ini tentunya tidak terlepas dari peranan sumber daya manusia.Pendapat seperti tersebut di atas sejalan dengan Undang-Undang Nomor 8 Tahun 1974 Tentang Pokok-Pokok Kepegawaian sebagaimana telah diubah dengan Undang-Undang Nomor 43 Tahun 1999 yang dalam penjelasannya bahwa kelancaran penyelenggaraan tugas pemerintahan dan pembangunan nasional sangat tergantung pada kesempurnaan aparatur Negara khususnya pegawai negeri.(Mustanir \& Abadi, 2017) Menghadapi kondisi pertama beban para pejabat lebih ringan dan tidak begitu pusing memikirkan distribusi nilai secara adil ke dalam masyarakat. Kondisi semacam ini secara teoritis dapat dijelaskan melalui konsep yang dikemukakan oleh Riggs(2005:27) dengan model masyarakat sederhana.. Masyarakat yang masih sederhana, berbagai fungsi masih memusat pada segelintir orang atau badan tertentu.Kemudian setelah melalui tahap perubahan,yang digambarkan seperti sinar yang memasuki kaca prisma, fungsi-fungsi 
tersebut akan memencar kearah spesialisasi.(Andi Uceng, 2019)

Gambaran seperti tersebut di atas berkaitan dengan beban kerja yang harus dipikul oleh seorang pimpinan organisasi.Beban tugas yang besar harus dipikul oleh seorang pimpinan menurut Manila (2006:3)dapat diatasi dengan tiga hal yaitu penerapan asas staf umum, pendelegasian wewenangdan tanggung jawab serta penyelesaian melalui bantuan suatu tim. Adanya debirokratisasi di Indonesia pada hakekatnyaadalah untuk menjawab tantangan masyarakat yang sedang berubah. Konseppelayanan one-stop service yang menghendaki adanya kejelasan prosedur,biaya maupun waktu menjadi dambaan semua kalangan masyarakat terutama kaum usahawan. Semangat de-birokratisasi menyongsong era industrialisasi sudah mulai dijiwai oleh aparat pemerintah pusat,pemerintah daerah maupun aparat pemerintah pusat yang ada di daerah.(Sapri, S., Mustanir, A., Ibrahim, M., Adnan, A. A., Wirfandi, 2019). Tetapi semangat tersebut saja tidak cukup untuk mengatasi berbagai masalah manajerial yang masih melilit organisasi kecamatan dalam usaha mencapai tujuan organisasi secara berhasil guna dan berdaya guna. Padahal hasil capai organisasi di tingkat kecamatan sebagai subsistem, berpengaruh langsung maupun tidak langsung terhadap hasil capai organisasi pemerintahan secara keseluruhan. Sejalan yang dikemukakan oleh Supriatna (2009:30) bahwa kualitas sumber daya manusia dan kualitas pemimpin khususnya merupakan faktor penentu sukses tidaknya organisasi atau usaha baik didunia bisnis maupun di dunia pendidikan,kesehatan, agama, sosial, politik, pemerintahan, dan menentukan keberhasilan lembaga atau organisasinya. Pemimpin harus mampu mengantisipasi perubahan yang terjadi, dapat mengoreksi kelemahan, sanggup membawa organisasi kepada sasaran dalam jangka waktu yang telah ditetapkan.(Mustanir \& Jusman, 2016). Kecamatan merupakan line office dari pemerintah daerah yang berhadapan langsung dengan masyarakat dan mempunyai tugas membina desa/kelurahan harus pula diselenggarakansecara berdaya guna danberhasil guna. Sebagai sebuah organisasi yang hidup dan melayani kehidupan masyarakat yang penuh dinamika, kecamatan mengalami banyak masalah sebagai organisasi administratif.(Fitrah et al., 2021).Kompleksitas masalah yang dihadapi berkaitan erat dengan banyaknya jumlah penduduk yang

dilayani,tingkaheterogenitasnya (asal usul, pendidikan,umur, kemampuan ekonomi) banyaknya desa/kelurahan bawahan. Hal ini seperti yang dikemukakan oleh Wasistiono (2001:55)bahwa di tingkat kecamatan, camat adalah manajer puncak, oleh karena itu camat juga menjalankan keempat fungsi manajemen secara berimbang. Tanpa adanya dukungan pegawai yang memadai kualitas maupun kuantitasnya, maka camat akan lebih banyak menghabiskan waktu dan pemikirannya dibelakang meja menyelesaikan pekerjaanpekerjaan yang bersifat teknis administratif.(Mustanir et al., 2021). Berdasarkan hal tersebut dapat dikatakan bahwa kunci keberhasilan organisasi terletak pada kinerja pegawaipegawainya Pelaksanaan pekerjaan oleh para pegawai di lingkungan organisasi pemerintahan kecamatan pada dasarnya berlangsung dalam kondisi pegawai sebagai manusia, suasana batin dan psikologis seorang pegawai sebagai individu dalam masyarakat organisasi yang menjadi lingkungan kerjanya sangat besar pengaruhnya pada pelaksanaan pekerjaannya. Suasana batin itu terlihat dalam semangat atau gairah kerja yang menghasilkan kegiatan kerja sebagai kontribusi bagi pencapaian tujuan organisasi tempatnya bekerja. Kenyataan menunjukkan bahwa dari segi psikologis, bergairah atau bersemangat dan sebaliknya tidak bergairah atau tidak bersemangat seorang pegawai dalam melaksanakan pekerjaannya sangat dipengaruhi oleh motivasi kerja yang mendorongnya. Berdasarkan hal tersebut di atas maka setiap aparatur pemerintah memerlukan 
motivasi yang kuat agar bersedia melaksanakan pekerjaan secara bersemangat, bergairah dan berdedikasi sehingga dapat memenuhi kualitas yang diharapkan masyarakat, karena hubungan antara motivasi dan prestasi kerja adalah sesuatu yang positif, meningkatnya motivasi akan menghasilkan lebih banyak usaha dan prestasi kerja yang lebih baik. Prinsip tersebut tidak menutup kemungkinan kondisi bahwadalam keadaan terpaksa seseorang mungkin saja melakukan sesuatu yang tidak disukainya. Seiring dengan besarnya tuntutan akan penerapan good governance, tuntutan akan pelayanan publik yang berkualitas juga menjadi semakin besar. Pemerintah merespon tuntutan ini dengan menetapkan tahun 2004 sebagai tahun peningkatan pelayanan publik. Pemerintah juga telah mengeluarkan berbagai kebijakan dalam rangka meningkatkan pelayanan, seperti misalnya pelayanan prima dan standar pelayanan minimal. Akan tetapi perbaikankualitas masih belum berjalan sebagaimana diharapkan.Pemberian motivasi merupakan factor penting dalam meningkatkan kinerja pegawai,dimana pemberian motivasi akan berdampak positif bagi pegawai itu sendiri, namun pada kenyataanya motivasi kerja pegawai pada Kantor Kecamatan Baranti Kabupaten Sidenreng Rappang itu menurun. Hal ini dapat dilihat bahwa dalam menjalankan tugas masing-masing pegawai kurang termotivasi,hal ini disebabkan karena banyak faktor yang memengaruhi, misalnya kurangnya pujian,penghargaan, tunjangan hari raya, bonus,mesin yang baik, ruangan kerja, suasana kerja, penempatan yang tepat.Fenomena sebagaimana tersebut di atas, mengisyaratkan bahwa manajemen sebagai proses mendayagunakan orang lain untuk mencapai suatu tujuan, hanya akan berlangsung efektif dan efisien jika para pimpinan mampu memotivasi para bawahan dalam melaksanakan tugas dan tanggung jawabnya. Organisasi pemerintahan perlu didukung oleh seorang pemimpin yang memiliki jiwa kepemimpinan dengan menunjukkan dirinya sebagai pemimpin yang profesional, yang mampu menggerakkan dan memotivasi bawahan dalam rangka pencapaian tujuan organisasi. Oleh sebab itu penulis tertarik untuk meneliti masalah dengan judul Peningkatan Motivasi Kerja Aparatur dalam Penyelenggaraan Pemerintahan di Kantor Kecamatan Baranti Kabupaten Sidenreng Rappang.

Motivasi berasal dari kata latin movere yang berarti dorongan, keinginan, sebab, atau alasan seseorang melakukan sesuatu.Menurut Manullang dalam manajemen personalia (2002:150), motivasi adalah pemberian kegairahan bekerja kepada karyawan. Dengan pemberian motivasi dimaksudkan pemberian daya perangsangkepada karyawan yang bersangkutan agar karyawan tersebut bekerja dengan segal upayanya. Sedangkan menurut Handoko(2009:9), motivasi diartikan sebagai keadaan dalam pribadi seseorang yang mendorong keinginan individu untuk melakukan kegiatan-kegiatan tertentu guna tujuan Manfaat motivasi yang utamaadalah menciptakan gairah kerja,sehingga produktivitas meningkat. Sementaraitu, manfaat yang diperoleh karena bekerja dengan orang-orang yang termotivasi adalah pekerjaan dapat diselesaikan dengan tepat.Artinya pekerjaan diselesaikan sesuai standar yang benar dan dalam skala waktu yang sudah ditentukan, serta orang senang melakukan pekerjaannya. Sesuatu yang dikerjakan karena ada motivasi yang mendorong akan membuat orang senang mengerjakannya. Orang pun akan merasa dihargai/diakui, hal ini terjadi kerena pekerjaannya itu betulbetul berharga bagi orang yang termotivasi, sehingga orang tersebut akan bekerja keras. Hal ini dimaklumi karena dorongan yang begitu tinggi menghasilkan sesuai target yang mereka tetapkan. Kinerjanya 
akan dipantau oleh individu yang

bersangkutan dan tidak akan membutuhkan terlalu banyak pengawasan serta semangat juangnya akan tinggi (Arep Ishak dan Hendri Tanjung, 2003: 16-17).Indikasi turunnya motivasi kerja penting diketahui oleh setiap perusahaan, karena dengan pengetahuan tentang indikasi ini akan dapat diketahui sebab turunnya motivasi kerja.Dengan demikian perusahaan dapat mengambil tindakan-tindakan pencegahan atau pemecahan masalah sedini mungkin Indikasi-indikasi turunnya motivasi kerja antara lain sebagai berikut.Turunnya produktivitas kerja: Turunnya produktivitas kerja ini dapat diukur atau dibandingkan dengan waktu sebelumnya.Produktivitas kerja yang turun ini dapat terjadi karena permasalahan, penundaan pekerjaan dan sebagainya. Untuk dapat mengetahui tinggi atau rendahnya produktivitas kerja,maka perusahaan harus membuat standar kerja. Tingkat absensi yang tinggi: Pada umumnya apabila semangat kerja turun, maka karyawan akanmalas untuk datang bekerja.(Ahmad mustanir, monalisa ibrahim, Muhammad rusdi, 2016)Untuk melihat apakah naiknya tingkat absensi tersebut merupakan indikasi turunnya semangat kerja, maka perusahaan tidak boleh melihat tingkat absensi ini secara perseorangan tetapi harus melihat secararata-rata.

Menurut Frederick Herzberg dalam(Cushway \& Lodge, 2005 : 139) bahwa motivasi kerja dapat diukur melalui indicator adalah Kondisi kerja, Kebijakan organisasi,Kehidupan di tempat kerja, Gaji dantunjangan, Pengakuan, Minat pada pekerjaan,dan Tanggung jawab.Menurut Hasibuan (2003:86) bahwa faktor-faktor yang mempengaruhi motivasi terbagi menjadi dua metode motivasi :

1. Motivasi Langsung, yaitu motivasi yang diberikan secara langsung kepada setiap individu karyawan untuk memenuhi kebutuhan serta kepuasannya. 2. Motivasi Tak Langsung, yaitu motivasi yang diberikan hanya merupakan fasilitasfasilitas yang mendukung serta menunjang gairah kerja/kelancaran tugas sehingga para karyawan betah dan bersemangat melakukan pekerjaan.Menurut Kamus Besar Bahasa Indonesia yang dimaksud dengan aparat adalah badan pemerintahan, instansi pemerintah, pegawai negeri, alat Negara. Sedangkan istilah aparatur pemerintah diartikan sebagai pegawai negeri, alat Negara, aparatur Negara. Kata aparatur sendiri berarti perangkat alat (Negara,pemerintah), para pegawai negeri.(ahmad mustanir, hariyanti hamid, 1929) Aparatur pemerintah merupakan alat kelengkapan Negara terutama meliputi bidang kelembagaan,ketatalaksanaan, dan kepegawaian yang mempunyai tanggung jawab melaksanakan roda pemerintahan sehari-hari.Aparatur dapat diartikian sebagai alat Negara atau aparat pemerintah. Jadi dapat dikatan bahwa aparatur merupakan alat perlengakapan negara yang terutama meliputi bidang kelembagaan, ketatalakasana dan kepegawaian yang mempunyai tanggung jawab mejalankan roda pemerintahan seharihari.Dengan demikian pengertian aparatur tidak hanya dikaitkan dengan orangnya(person) tetapi juga dengan fasilitas atau punketentuan-ketentuan organisasi dansebagainya.

\section{B. METODE PENEELITIAN}

Penelitian ini memiliki 2 (dua) variabel,variabel pertama disebut sebagai variabel

bebas yaitu peningkatan motivasi kerja aparatur dan variabel kedua sebagai variabel terikatnya yaitu penyelenggaraan pemerintahan. Desain penelitian yang 
digunakan adalah menggunakan deskriptif kuantitatif.Populasi dalam penelitian iniadalah seluruh pegawai di Kantor Kecamatan Baranti berjumlah 44 orang Sampel sebanyak 44 orang. Teknik pengumpulan data yang digunakan adalah observasi, wawancara,kuesioner, dan studi kepustakaan. Sedangkan teknik analisis data yang digunakan melalui dengan menggunakan pendekatan teknik tabulasi frekuensi.

\section{HASIL DAN PEMBAHASAN}

Berdasarkan data mengenai Peningkatan Motivasi Kerja Aparatur dalam

Penyelenggaraan Pemerintahan di Kantor Kecamatan Baranti Kabupaten Sidenreng Rappang dapat diambil kesimpulan bahwa 67,57 \% konsep Peningkatan Motivasi Kerja Aparatur dalam Penyelenggaraan

Pemerintahan di Kantor Kecamatan Baranti Kabupaten Sidenreng Rappang sudah berjalan dengan baik yakni kondisi kerja 68 $\%$, jadwal apel $67 \%$, kebersihan atau kerja bakti bersama $69 \%$, lingkungan tempat kerja $70 \%$, gaji dan tunjangan $68 \%$, ucapan selamat pada aparat yang berprestasi $67 \%$, minat dan pekerjaan $64 \%$, tanggung jawab $68 \%$ dengannilai $67,57 \%$ berjalan dengan baik. Analisis data tersebut diambil berdasarkan kumulatif dari keseluruhan konsep Peningkatan Motivasi Kerja Aparatur dalam Penyelenggaraan Pemerintahan di Kantor Kecamatan Baranti Kabupaten Sidenreng Rappang yang perhitungannya dilakukandengan cara menjumlahkan keseluruhanjawaban responden sesuai kriteria, kemudian dibagi dengan jumlah konsep yang ada. Sehingga hasil kumulatif dari konsep

Peningkatan Motivasi Kerja Aparatur dalam Penyelenggaraan Pemerintahan di Kantor Kecamatan Baranti Kabupaten Sidenreng Rappang adalah 67,57 \% yang termasuk kualifikasi baik. Berdasarkan data tersebut di atas dapat diambil kesimpulan bahwa
$67,75 \%$ konsep faktor-faktor yang memengaruhi Peningkatan Motivasi Kerja Aparatur dalam Penyelenggaraan Pemerintahan di Kantor Kecamatan Baranti Kabupaten Sidenreng Rappang berjalan dengan baik. Sehingga hasil kumulatif dari konsep faktor-faktor yang memengaruhi Peningkatan Motivasi Kerja Aparatur dalam Penyelenggaraan Pemerintahan di Kantor Kecamatan Baranti Kabupaten Sidenreng Rappang yaitu factor motivasi langsung terdiri dari faktor pujian $66 \%$, penghargaan $68 \%$, tunjangan hari raya $67 \%$, bonus $67 \%$ dengan capaian 67 $\%$ kategoribaik, faktor motivasi tak langsung terdiri dari mesin atau komputer yang baik $69 \%$, ruangan kerja yang terang $66 \%$, suasana kerja $69 \%$,penempatan yang tepat $70 \%$, dengan capaian $67,75 \%$

dikategorikan baik.

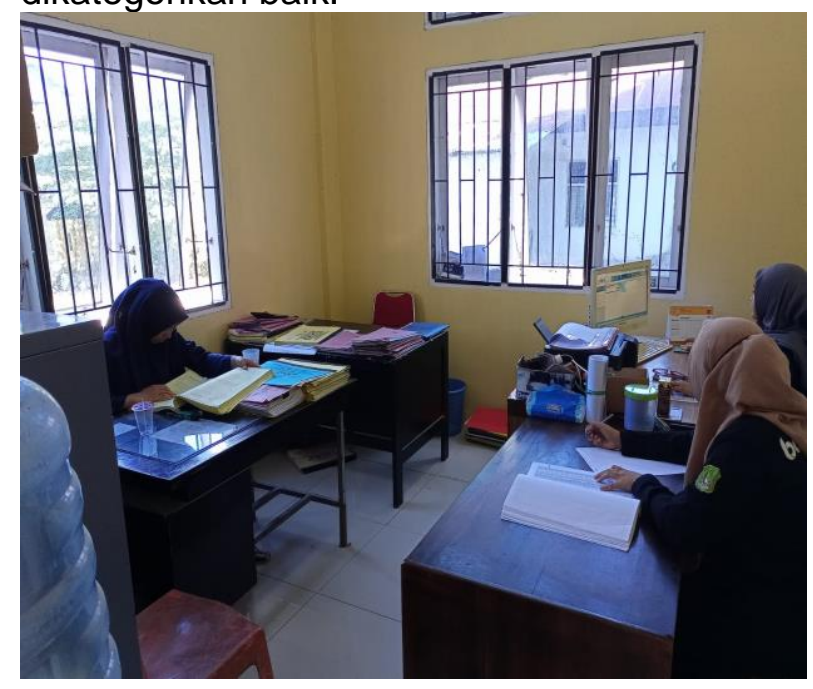

\section{KESIMPULAN}

Berdasarkan permasalahan, tujuan, dan manfaat serta hasil pembahasan yang telah diuraikan pada bab sebelumnya, maka dapat ditarik kesimpulan, sebagai berikut: 1. Peningkatan Motivasi Kerja Aparatur dalam Penyelenggaraan Pemerintahan di Kantor 
Kecamatan Baranti sudah efektif dan efisien berdasarkan dari hasil penelitian dengan adanya tanggapan responden yaitu pegawai bahwa Peningkatan Motivasi Kerja Aparatur sangat berpengaruh terhadap penyelenggaraan pemerintahan,maka sudah bisa dikatakan baik dan efektif dalam Peningkatan Motivasi Kerja Aparaturnya, hal ini dapat dilihat dari Kondisi Kerja, Kebijakan Organisasi,Kehidupan di Tempat Kerja, Gaji dan tunjangan, Pengakuan, Minat pada pekerjaan, Tanggung jawab.

2. Peningkatan Motivasi Kerja Aparatur dalam Penyelenggaraan Pemerintahan di Kantor

Kecamatan Baranti dipengaruhi oleh factor pujian, penghargaan, tunjangan hari raya, bonus, mesin atau komputer yang baik ruangan kerja yang terang, suasana kerja, penempatan yang tepat.

3. Adapun hasil yang paling tinggi faktorfaktor yang mempengaruhi peningkatan motivasi kerja aparatur dalam penyelenggaraan pemerintahan adalah penempatan yang tepat $70 \%$.

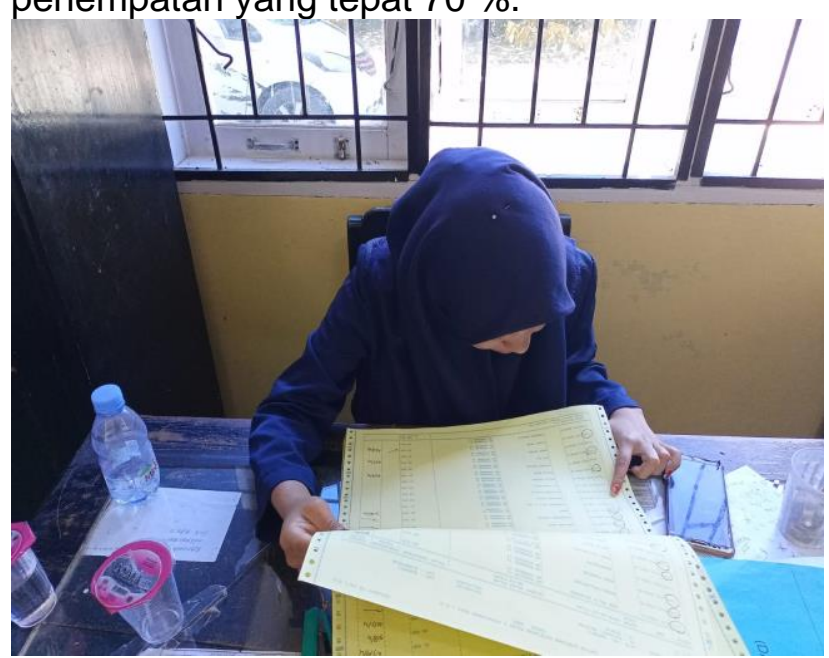

E. DAFTAR PUSTAKA

ahmad mustanir, hariyanti hamid, R. N. S. (1929). Perencanaan Partisipatif. Archiv Für Experimentelle Pathologie Und Pharmakologie, 141(5-6), 307328.
Ahmad mustanir, monalisa ibrahim, Muhammad rusdi, M. jabbareng. (2016). Pembangunan Partisipatif Dan Pemberdayaan Masyarakat. July, 123.

Andi Uceng, A. A. (2019). Analisis Tingkat Partisipasi Masyarakat Terhadap Pembangunan Sumber Daya Manusia Di Desa Cemba Kecamatan Enrekang Kabupaten Enrekang. MJurnal Moderat, 5(2), 1-17.

Fitrah, N., Mustanir, A., Akbari, M. S., Ramdana, R., Jisam, J., Nisa, N. A., Qalbi, N., Febriani, A. F., Irmawati, I., Resky S., M. A., \& Ilham, I. (2021). Pemberdayaan Masyarakat Melalui Pemetaan Swadaya Dengan

Pemanfaatan Teknologi Informasi Dalam Tata Kelola Potensi Desa. SELAPARANG Jurnal Pengabdian Masyarakat Berkemajuan, 5(1), 337. https://doi.org/10.31764/jpmb.v5i1.620 8

Mustanir, A., \& Abadi, P. (2017). Partisipasi Masyarakat Dalam Musyawarah Rencana Pembangunan Di Kelurahan Kanyuara Kecamatan Watang Sidenreng Kabupaten Sidenreng Rappang. Jurnal Politik Profetik, 5(2), 247-261. http://journal.uinalauddin.ac.id/index.php/jpp/article/vie wFile/4347/3986\%0Ahttp://journal.uinalauddin.ac.id/index.php/jpp/issue/view 1636

Mustanir, A., Dema, H., Syarifuddin, H., Irwan, \& Wulandari, K. M. S. (2018). Pengaruh motivasi dan partisipasi masyarakat terhadap pembangunan di kelurahan lalebata kecamatan panca rijang kabupaten sidenreng rappang. IImiah Clean Government, 2(1), 27-39. 
Mustanir, A., Fitriani, S., Adri, K., Nurnawati, A. A., \& Goso, G. (2020). Sinergitas Peran Pemerintah Desa dan Partisipasi Masyarakat Terhadap Perencanaan Pembangunan di Kabupaten Sidenreng Rappang (The Synergy of Village Government's Role and Community Participation in the Process of Development Planning in Sidenreng Rappang D. Journal of Government Science (GovSci), 2020, 1(2): 84-108, 2020(2), 84-108.

Mustanir, A., \& Jusman. (2016). Implementasi Kebijakan Dan Efektivitas Pengelolaan Terhadap Penerimaan Retribusi Di Pasar Lancirang Kecamatan Pitu Riawa Kabupaten Sidenreng Rappang. Jurnal IImiah Akmen, 13(3), 542-558. https://e-jurnal.stienobelindonesia.ac.id/index.php/akmen/articl e/view/69\%0Ahttps://e-jurnal.stienobelindonesia.ac.id/index.php/akmen/issue/ view/6

Mustanir, A., Rais, M., Razak, R., \& Mursalat, A. (2021). PEMBERDAYAAN BADAN USAHA MILIK DESA DENGAN TEKNOLOGI INFORMASI DIMASA PANDEMI COVID-19 DALAM terkomputerisasi dan masih dikerjakan secara manual sehingga sebelumnya dengan judul Prospek Pemasaran Potensi Hasil Pertanian Desa Carawali Melalui Pemanfaatan A. 5(5), 2-8.

Sapri, S., Mustanir, A., Ibrahim, M., Adnan,
A. A., Wirfandi, W. (2019). Peranan
Camat dan Partisipasi Masyarakat
Dalam Musyawarah Perencanaan
Pembangunan Di Kecamatan
Enrekang Kabupaten Enrekang.
MODERAT: Jurnal IImiah IImu

Pemerintahan, 5(2), 33-48.

https://jurnal.unigal.ac.id/index.php/mo derat/article/view/2127 